\title{
Российская этнология в начале XXI века: когнитивная структура дисциплины на основе анализа журнальных социтирований ${ }^{1}$
}

\author{
Б.Е. ВИНЕР*
}

\begin{abstract}
*Борис Ефимович Винер - кандидат социологических наук, старший научный сотрудник, Социологический институт. Адрес: 190005, Санкт-Петербург, 7-я Красноармейская, д. 25/14. E-mail: wienerras@yandex.ru

Цитирование: Винер Б.Е. (2017) Российская этнология в начале XXI века: когнитивная структура дисциплины на основе анализа журнальных социтирований // Мир России. Т. 26. № 3. С. 165-193. DOI: 10.17323/1811-038X-2017-26-3-165-193
\end{abstract}

Статья описывает когнитивную структуру российской этнологии на основе анализа социтирований. Выборка включает пристатейные ссылки из 159 российских этнологических и соииологических журналов и 9 продолжающчихся сборников, изданных в 2005-2009 годах. Использованы три количественных метода: иерархический дивизивный кластерный анализ, алгоритм выявления плотных сетей для анализа соичитирований и анализ социальных сетей. Набор выделенных благодаря этим методам и триангуляции исследовательских областей заметно отличается от рубрик, которые получил С.В. Соколовский, анализируя этнологические статьи из журнала «Этнографическое обозрение» за 1975-2000 годы. Основная разница состоит в том, что, в отличие от его рубрикации, которая базируется только на анализе названий статей, предложенный в настоящей статье метод демонстрирует наличие в составе этнологии, наряду с подразделениями, выделенными С.В. Соколовским, региональных исследовательских областей, каковыми являются "Восточнославянская этнология и фольклор», «Этнология Сибири», «Этнология народов уральской языковой семьи», «Этнология Средней Азии и Казахстана» и другие.

Ключевые слова: социология социальных наук, анализ социтирований, российская этнология, наукометрия, библиометрия, когнитивная структура науки

\footnotetext{
1 Работа выполнена по государственному заданию (тема «Структуры и дисциплинарные культуры в социальных науках, социальное знание и его инструментальные ресурсы», государственная регистрация № AAAA-A17-117030110148-1).
} 


\section{Введение}

Ученых всегда интересовало, каким образом структурируется знание внутри научных дисциплин, на какие исследовательские области они делятся, и какие более узкие направления исследований прослеживаются внутри изучаемых областей. В зависимости от применяемых инструментов можно получить разные картины внутренней структуры дисциплины.

Одним из первых методов описания структуры дисциплины является историографический метод, когда исследователь описывает историю деятельности занятых в ней ученых и их объединений, историю накопления знаний, формулирования, критики и переформулирования научных концепций. Именно этим путем идет Шерри Ортнер, рассматривая набор теорий в составе англоязычной антропологии [Ortner 1984]. Другим методом является анализ статей из ведущих дисциплинарных журналов за определенный период с опорой на их названия, резюме и ключевые слова и классификация этих статей в соответствие объекта и предмета: для российской этнологии хорошим примером здесь является статья С.В. Соколовского [Соколовский 2003]. Близок к этому и подход, используемый при разработке библиотечных классификаций, например, в прошлом советской, а ныне российской Библиотечно-библиографической классификации (ББК), которая, однако, разрабатывалась не одним исследователем, а большим коллективом с привлечением ведущих ученых для составления таблиц по конкретным наукам.

В приведенных выше примерах описания структуры научных дисциплин велико значение субъективного фактора. Представители различных национальных традиций, исследовательских школ, да и просто разные эксперты в процессе своей классификационной деятельности неизбежно производят неодинаковый конечный продукт. Способом уменьшения влияния субъективного фактора на представление о когнитивной структуре дисциплины является анализ социтирований. Американские социологи науки отмечают, что в свое время наукометристы «Смолл и Гриффит (1974) предложили анализ социтирований в качестве способа идентифицирования малых, неформальных групп ученых, которые играют основную роль в научных сдвигах» [Mullins, Hargens, Hecht, Kick 1977, p. 552]². Следует напомнить, что социтирование понимается как совместное цитирование в одной научной публикации двух каких-либо публикаций. «Сила социтирования определяется как число раз, когда два документа цитируются вместе: она дает понятный количественный способ для того, чтобы сгруппировать или связать цитируемые документы» [Small, Griffith 1974, p. 19]. Иными словами, этот метод предусматривает поиск одних и тех же социтирований, т.е. сочетаний названий двух конкретных публикаций, внутри некоторого набора публикаций, например, всех журнальных статей за определенный год, всех статей из выпусков какого-либо журнала за несколько лет и т.п. В качестве примера социтирования приведу сочетание работ М.К. Азадовского и С.В. Соколовского из списка литературы к данной статье. При желании не составит большого труда проверить, сколько раз повторяется это сочетание, допустим, во всей совокупности статей, представленных в Научной электронной

2 В СССР независимо от Г. Смолла [Small 1973] этот метод предложила И.В. Маршакова [Mаршакова 1973]. 
библиотеке (НЭБ). Для количественного анализа найденных социтирований используются методы, описанные в следующей главе.

Значительную сложность представляет собой определение статусов групп цитирований, выделенных в результате анализа социтирований, и соотнесение их с исследовательскими областями. Основываясь на рассуждениях британского социолога Ричарда Уитли [Уитли 1980, с. 229-231, 234]3 , можно предположить, что в качестве отправного момента в данном проекте правильным было бы считать исследовательскими областями те группы цитирований (или совокупности ссылок), которые аналитик в состоянии идентифицировать: он может приписать такой группе общее название, охватывающее тематику большинства представленных в этой группе ссылок.

Целью статьи является исследование когнитивной структуры современной российской этнологии при помощи трех разновидностей метода анализа социтирований (дивизивного кластерного анализа, анализа плотных сетей Шилдта и сетевого анализа). Полученные результаты позволят сравнить современное состояние этой структуры как таковую в иные периоды, так и со структурами этнологии или социально-культурной антропологии в других странах. Вспомогательной задачей, как это обычно бывает в работах по наукометрии, станет отработка процедуры анализа социтирований применительно к заявленной цели.

\section{Данные и методы}

Анализ социтирований может применяться в разных целях, в частности, для поиска так называемых исследовательских фронтов, под которыми понимаются сравнительно небольшие совокупности высокоцитируемых статей [Upham, Small 2010, p. 17]. Данные для выявления этих фронтов берутся из больших баз данных (например, из баз на платформе Web of Science), причем в выборку включаются только высокоцитируемые работы за определенный год или квартал по всем наукам, присутствующим в базе. Порог отсечения менее цитируемых работ вводится исследователем. Далее возможно либо отслеживание ссылок на конкретные публикации, как это делают, скажем, в журнале Scientometrics большинство авторов, работающих с социтированиями, либо отслеживание ссылок только на названия журналов без распознавания содержащихся в них статей [Moody, Light 2006].

В отличие от представителей макроподхода, при микроподходе к социтированиям используются данные из одного или нескольких журналов по одной дисциплине за несколько лет при невысоких нижних порогах цитирования [Gmür 2003; Schildt, Mattson 2006]. Мой подход заимствует из макроподхода идею работы с большими базами данных, а из микроподхода - ограничение одной-двумя дисциплинами в выборке и использование ссылок за ряд лет при низких порогах цитирований.

3 Р. Уитли различает в когнитивной структуре науки четыре уровня. Перечисляю их в порядке от верхних к нижним: дисциплины, специальности, исследовательские области и проблемные ситуации. Важно отметить, что Р. Уитли не дает строгих определений этих феноменов. 


\section{Выборка}

Выборка для исследования образована путем отбора статей за 2005-2009 гг. из российских журналов по социологии и этнологии. Социологические журналы включены в выборку для того, чтобы учесть такую важную область, как этносоциология. В выборку вошли публикации, процитированные в 156 журналах и 9 продолжающихся сборниках, но при этом по ряду лет имеются лакуны из-за отсутствия номеров журналов в Интернете или петербургских библиотеках. Этнологическая часть выборки включает 71 название журналов: здесь присутствуют все журналы, имеющие в названии слова «этнология» и «этнография» и производные от них, а также значительная часть журналов на русском языке, которые в Научной электронной библиотеке попадают под код тематического рубрикатора ГРНТИ 03.61.00 - «Этнография и историческая антропология». Кроме того, в число отобранных журналов входят те, которые имеют в своем названии слова «вестник», «известия», «проблемы» и более или менее регулярно публикуют статьи по этнологии. Сборники представлены следующим набором: «Алгебра родства», «Материалы полевых исследований МАЭ РАН», «Полевые исследования Института этнологии и антропологии РАН», «Расы и народы», «Сборник МАЭ», «Этнологические исследования по шаманству и иным традиционным верованиям и практикам», Studia Etnologica. Последовательность работы с данными представлена на рисунке 1 .

\begin{tabular}{|l|}
\hline ШАГ 1. \\
Скачивание и \\
копирование \\
журнальных \\
ссылок \\
\end{tabular}
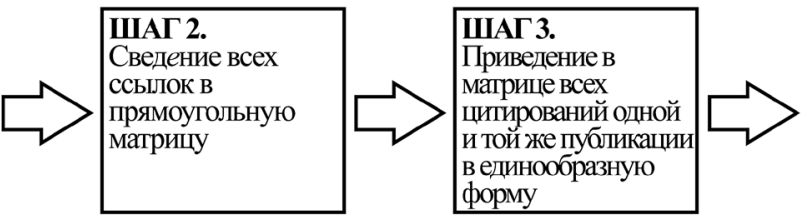

ШАГ 4. Удаление из прямоугольной матрицы публикаций, процитированных менее 2 раз

\section{ШАГ 8.} Проведение сетевого анализа социтирований на основе квадратной матрицы

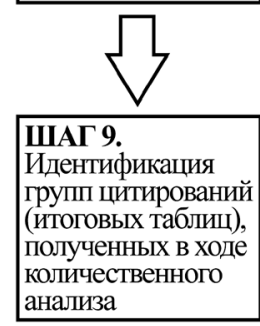

\section{ШАГ 7.} Проведение анализа плотных сетей на основе квадратной матрицы

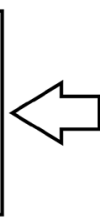

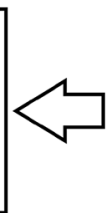

ШАГ 5. Преобразование прямоугольной матрищы в квадратную матрицу 
При работе алгоритмов по вычленению групп цитирований публикации, называемые в исторических науках источниками, не отделяются от тех работ, которые у представителей исторических наук принято называть «литературой». $\mathrm{B}$ принципе, исследователь еще на этапе формирования матрицы мог бы разделить эти книги и статьи и исключить источники из рассмотрения. Однако сложность заключается в том, что одна и та же публикация может выступать в обеих ипостасях: например, книга Ф.П. Кеппена «Ученые труды П.С. Палласа» относится к разряду литературы о П.С. Палласе, но в то же время она является источником для работ о Ф.П. Кеппене. Невозможно подсчитать, сколько раз та или иная публикация выступала в одной из этих ролей, поэтому приходится мириться с указанным недостатком.

\section{Предварительная обработка данных}

Ссылки из списков литературы к журнальным статьям были сведены в прямоугольную матрицу в формате Excel, столбцы которой представляли 8304 цитирующих статьи, а строки - свыше 113477 цитирований. Сюда не вошли републикации и переводы статей, не написанные специально для российских журналов. Далее необходимо было объединить в одну строку таблицы Excel цитирования одной и той же публикации, если она была процитирована неоднократно. Процитированные публикации были приведены к единой форме библиографического описания, что делалось вручную и было чрезвычайно трудоемким. Необходимость такой стандартизации вызвана отсутствием единообразных требований к ссылкам у редакций журналов. В отредактированной матрице со сложенными в одну строку ссылками на одну и ту же публикацию находилось уже 89638 строк.

Полученная прямоугольная матрица с нижним порогом цитирований 1 (т.е. в матрицу вошли все публикации, процитированные хотя бы один раз) для последующих вычислений преобразовывалась в квадратную матрицу 89638 х 89638, сторонами которой выступали процитированные публикации.

Сложной проблемой становится определение порогов для выполнения процедур количественного анализа. Конечно, исследователям хотелось бы использовать полученные матрицы в полном объеме, однако, помимо аппаратнопрограммных сложностей, таких как неспособность компьютера недостаточной мощности или конкретной программы обработать большой массив данных, здесь появляются и другие затруднения. Например, авторы многих статей из нескольких исследовательских областей могут ссылаться на одну хорошо известную книгу или статью, написанную, допустим, выдающимся теоретиком. Тогда возникает риск, что в результате количественного анализа вместо нескольких самостоятельных областей возникнет одна большая область. Чтобы этого не происходило, И.В. Маршакова рекомендует исключать из анализа цитирующие статьи, имеющие ссылки более чем на 40 публикаций, полагая, что подобные статьи «относятся к библиографиям» [Маршакова 1973, с. 6]. Такая позиция справедлива в отношении публикаций по некоторым естественным наукам, однако в социальных и гуманитарных науках большое число ссылок - обычное 
явление, поэтому в данном проекте невозможно исключить из выборки статьи с большим числом ссылок ${ }^{4}$.

Вопрос об определении нижнего порога является не менее сложным. Мой опыт работы с результатами на пороге 1 показывает, что довольно часто получались группы цитирований, по сути дела, являвшиеся совокупностью ссылок к одной цитирующей статье. Это особенно относится к тем цитирующим статьям, которые ссылаются на литературу, мало используемую другими авторами. Более того, такие группы цитирований могут быть результатами анализа и на порогах 2 и 3: например, подобное происходило с литературой, цитируемой в статьях Ю.Е. Березкина. Дело в том, что сферой интересов этого автора является сравнительная мифология, область, в которой пока отсутствует достаточное количество работ других российских исследователей. В ряде случаев подобный феномен возникает и у других авторов, но его можно исключить за счет повышения нижнего порога цитирований, однако в этом случае теряется значительная часть данных.

В уже упоминавшейся статье И.В. Маршаковой без объяснений в качестве нижнего избирается порог в 3 цитирования [Маршакова 1973, с. 6]. Еще в одном материале тот же автор без какого-либо обоснования при работе с социтированиями использует нижний порог в 2 ссылки [Маршакова-Шайкевич 2004, с. 32]. Более того, не удалось обнаружить каких-либо обоснований величины нижнего порога и в публикациях других авторов. В предыдущих публикациях автора настоящей статьи с коллегами были представлены результаты обработки данных на порогах цитирований 4 и 7. Это было связано с тем, что для меньших массивов данных легче было подобрать технику и программное обеспечение, и переход к более низким порогам стал возможен только с обретением такого опыта. В настоящем исследовании, несмотря на сложности, описанные на примере с работами Ю.Е. Березкина, с целью избежать большой потери данных был избран порог в 2 цитирования. В этом случае матрица, значительно теряя в размерах, сжалась до квадрата 16559 х 16559.

\section{Методы анализа данных}

В качестве методов количественной обработки данных были использованы дивизивный кластерный анализ, анализ плотных сетей Шилдта и сетевой анализ.

Дивизивный кластерный анализ. Иерархический кластерный анализ рекомендуется применять при невозможности предварительного предположения о количестве получаемых кластеров [Kaufman, Rousseeuw 1990, p. 44]. При этом методе можно идти снизу вверх, когда отдельные единицы наблюдения (в нашем случае социтирования) объединяются во все более крупные группы (агломеративный кластерный анализ). Когда же число единиц наблюдения в выборке превышает 100, предпочтительнее выбирать дивизивный кластерный анализ [Arabie, Hubert, Carroll 2005, p. 318], на каждом новом шаге которого программный алгоритм разбивает совокупность социтирований надвое, получая все более мелкие группы. Исследователь эвристическим путем принимает решение о том, на каком шаге пре-

\footnotetext{
4 Далее будет показано, что подобную сложность позволяет преодолеть разработанный Г. Шилдтом метод
} анализа плотных сетей. 
кратить выполнение процедуры деления [Arabie, Hubert, Carroll 2005, pp. 318-319]. Согласно рекомендации И.В. Маршаковой, при дивизивном кластерном анализе социтирований в расчеты для предотвращения случайных влияний цитирующих статей с малым количеством ссылок необходимо вводить поправочный коэффициент, основанный на распределении Пуассона [Маршакова 1981, с. 16-17].

Анализ плотных сетей Шилдта. Данный метод, основанный на расчете коэффициента Жаккара, разработан ученым из Финляндии Г. Шилдтом и описан совместно с Ю. Матссоном как a dense network sub-grouping algorithm 5 . Одним из достоинств метода является то, что он «отбрасывает широко цитируемые книги ${ }^{6}$, которые не принадлежат к какому-либо внутренне связному классу литературы» [Schildt, Mattson 2006, pp. 143-163]. Свою работу алгоритм начинает с выбора в квадратной матрице двух процитированных работ, имеющих наибольшее количество совместных социтирований. К этой диаде поочередно добавляются социтирования в порядке убывания средней силы связи социтирования. Процедура повторяется до достижения средней силой связи критерия (т.е. определенной величины коэффициента Жаккара), заранее установленного исследователем ${ }^{7}$. В этот момент полученная группа изымается из матрицы, и процедура возобновляется до тех пор, пока из матрицы не будут выбраны все плотные сети [Schildt, Mattson 2006, pp. 146-147].

Сетевой анализ основан на теории графов и может использоваться в изучении социтирований. Как было показано ранее [Сафонова, Винер 2013], для сетевого анализа социтирований в описываемой выборке оптимальным оказался предложенный нидерландским биоинформатиком Стейном ван Донгеном алгоритм, который основан на свойствах случайных графов Маркова [van Dongen 2000].

Использование разных методов для анализа отдельно взятого массива данных является одним из типов триангуляции [Schutt 1996, p. 355], которая позволяет компенсировать недостатки разных исследовательских методов ${ }^{8}$. Готовые результаты количественного анализа, извлеченные в табличной форме, содержат выходные данные публикаций и количество их цитирований в статьях, попавших в выборку 9 .

\section{Результаты}

В таблице 1 представлены результаты трех методов анализа социтирований для данных по социологии и этнологии. Группы единиц наблюдения, полученные в

\footnotetext{
5 Алгоритм группирования плотных сетей.

6 К книгам надо добавить также статьи и прочие цитирующиеся публикации.

7 В ходе расчетов по моей матрице кандидат биологических наук В.Б. Нечаев установил, что в нашем случае величина критерия отсечения намного меньше, чем у разработчиков метода, и ввел для расчетов в качестве такого критерия величину коэффициента 0,0015 . Впоследствии в ходе эмпирической работы по идентификации полученных в процессе анализа сетей выяснилось, что в них надо отсекать процитированные работы, сила связи которых с работой, от которой начиналось выделение сети, составляла во взвешенном виде 0,21-0,22 и меньше процентов от величины коэффициента Жаккара.

8 Данные с помощью кластерного анализа и метода анализа Шилдта обрабатывал кандидат биологических наук В.Б. Нечаев, а с помощью сетевого анализа - кандидат социологических наук М.А. Сафонова. Преобразование данных для работы в нескольких статистических пакетах осуществлял кандидат социологических наук К.С. Дивисенко.

9 Далее в тексте во избежание путаницы таблицы с конечными результатами анализа называются итоговыми таблицами.
} 
результате кластерного анализа, принято называть кластерами, в результате сетевого анализа - группированиями, в результате анализа плотных сетей Шилдта плотными сетями. В данной статье в качестве родового термина применительно к результатам анализа социтирований используется термин группы цитирований.

Таблица 1. Количественные результаты идентификации групп цитирований для трех методов анализа социтирований по социологии и этнологии (при нижнем пороге в 2 цитирования)

\begin{tabular}{|l|c|c|c|}
\hline Категории групп публикаций & $\begin{array}{c}\text { Кластерный } \\
\text { анализ }\end{array}$ & $\begin{array}{c}\text { Анализ } \\
\text { плотных сетей }\end{array}$ & $\begin{array}{c}\text { Сетевой } \\
\text { анализ }\end{array}$ \\
\hline Число строк в матрице до проведения расчетов & 16559 & 16559 & 16559 \\
\hline $\begin{array}{l}\text { Число публикаций, попавших в идентифицированные } \\
\text { групп, отвечающие введенным критериям }\end{array}$ & 4278 & 2570 & 9818 \\
\hline $\begin{array}{l}\text { Число публикаций, попавших в идентифицированные } \\
\text { групп, не отвечающие введенным критериям }\end{array}$ & 2650 & 763 & 4393 \\
\hline $\begin{array}{l}\text { Число публикаций, попавших } \\
\text { во все идентифицированные группы, } \\
\text { отвечающие и не отвечающие введенным критериями }\end{array}$ & 6928 & 3333 & 14211 \\
\hline
\end{tabular}

Из таблицы 1 видно, что максимальное количество публикаций, попавших в идентифицируемые группы, дает сетевой анализ, а минимальное - анализ плотных сетей. Далее будут описаны результаты только для тех групп цитирований, которые идентифицировались как этнологические и этносоциологические, а также для тех групп цитирований, которые ближе к этнологии, чем к социологии. Показательно, что группы цитирований, образующиеся посредством разных методов, близки друг к другу, если не менее четверти публикаций в группе, полученной одним методом, обнаруживаются также в группе, сформированной другим методом. Данная процедура сравнения осуществлялась вручную.

Идентификация групп публикаций проводилась путем просмотра названий публикаций, попавших в группы (т.е. в итоговые таблицы), при необходимости дополнительно собиралась информация об авторах. Поскольку в социальных и гуманитарных науках, в отличие от естественных, объект исследования (исходя из названия) не всегда понятен, во многих случаях приходилось обращаться к аннотациям публикаций или к самим публикациям, а также к текстам цитирующих их статей ${ }^{10}$. Экспериментальным путем было установлено, что приемлемые результаты при идентификации итоговых таблиц достигаются при наличии трех условий: (1) количество процитированных публикаций должно быть не менее 5; (2) число статей, ссылающихся на процитированные публикации, в совокупности должно быть не менее 50; (3) не менее половины процитированных статей и не менее половины ссылок на эти статьи должны совпадать с названием, приписываемым та-

10 Именно поэтому процедуру идентификации должен проводить специалист в соответствующих областях, а не любой исследователь и тем более не компьютерная программа. 
блице. Если хотя бы одно из этих условий нарушалось, группа цитирований считалась не отвечающей введенным критериям.

В таблице 2 представлены результаты, полученные с помощью описанных методов и касающиеся только этнологии. Как и в случае с объединенными для социологии и этнологии результатами в таблице 1, видно, что максимальное число публикаций, попавших в идентифицированные группы, дает сетевой анализ, а минимальное - анализ плотных сетей.

\section{Таблица 2. Количественные результаты идентификации групп цитирований для трех методов анализа социтирований по этнологии (при нижнем пороге в 2 цитирования)}

\begin{tabular}{|l|c|c|c|}
\hline Категории групп публикаций & $\begin{array}{c}\text { Кластерный } \\
\text { анализ }\end{array}$ & $\begin{array}{c}\text { Анализ } \\
\text { плотных сетей }\end{array}$ & $\begin{array}{c}\text { Сетевой } \\
\text { анализ }\end{array}$ \\
\hline $\begin{array}{l}\text { Число публикаций, попавших в идентифицированные } \\
\text { группы, отвечающие введенным критериям }\end{array}$ & 1579 & 919 & 3214 \\
\hline $\begin{array}{l}\text { Число публикаций, попавших в идентифицированные } \\
\text { группы, не отвечающие введенным критериям }\end{array}$ & 597 & 218 & 760 \\
\hline $\begin{array}{l}\text { Число публикаций, попавших во все } \\
\text { идентифицированные группы, отвечающие } \\
\text { и не отвечающие введенным критериями }\end{array}$ & 2176 & 1137 & 3974 \\
\hline
\end{tabular}

\section{Таблица 3. Плотная сеть 530. «Этническая экономика и этническое предпринима- тельство» $^{11}$}

Кальмина Л.В. (2003) Еврейские общины Восточной Сибири (середина XIX века февраль 1917 года). Улан-Удэ.

Кальмина Л.В., Курас Л.В. (1999) Еврейская община в Западном Забайкалье (60-е годы ХІХ века - февраль 1917). Улан-Удэ.

Гончаров Ю.М. (2000) Еврейское купечество Западной Сибири во второй половине

XIX - начала XX в. // Диаспоры. № 3. С. 155-172.

Юрий Михайлович Гончаров - окончил исторический факультет Алтайского ГУ, д.и.н., профессор кафедры отечественной истории Алтайского государственного университета. Исследовательские интересы: история предпринимательства, сословного строя, семьи, быта, городской жизни Сибири и Алтая XVII - начала XX в.

11 Отношение идентифицированных публикаций ко всем публикациям в сети 9/14. Отношение идентифицированного количества цитирований ко всем цитированиям в сети 27/50. 6 источников пересекаются с группированием 5 «Нации, национализм, этнонациональная политика», 4 источника - с группированием 12 «Диаспоры», 5 источников - с кластером 02496 «Этническое предпринимательство».

В ходе дальнейшей работы материалы таблиць 3 обозначались индексом Ш530: 9/14(27/50), где буква Ш указывает на то, что это результат анализа плотных сетей Шилдта, 530 - порядковый номер плотной сети, а числовые значения взяты из описанных выше в данной сноске отношений идентифицированных публикаций и цитирований ко всем публикациям и цитированиям в таблице 3. В обозначении таблиц, полученных с помощью кластерного анализа, присутствует буква К (кластер), а посредством сетевого анализа - буква Г (группирование). 


\begin{tabular}{|c|c|}
\hline $\begin{array}{l}\text { Вибе П.П. (2001) Вклад немцев-предпринимателей в становление крупных культурных } \\
\text { хозяйств в Сибири // Немцы в России. Российско-немецкий диалог. СПб. С. 399-411. } \\
\text { Петр Петрович Вибе - окончил истфак Омского ГУ и аспирантуру Томского ГУ, д.И.н., } \\
\text { директор Омского государственного историко-краеведческого музея. Исследователь- } \\
\text { ские интересы: история и культура сибирских немцев. }\end{array}$ & 2 \\
\hline $\begin{array}{l}\text { Шайдуров В.Н. (2003) Формирование и социально-экономическое развитие немецкой } \\
\text { диаспоры на Алтае: конец XIX - начало XX в. Барнаул. }\end{array}$ & 2 \\
\hline $\begin{array}{l}\text { Воронков В.М. (2000) Существует ли этническая экономика? // Труды Центра независимых } \\
\text { социологических исследований. Выпуск 8. СПб. С. 42-47. } \\
\text { Виктор Михайлович Воронков - окончил Латвийский государственный } \\
\text { университет по специальности экономическая кибернетика, директор Центра } \\
\text { независимых социологических исследований, бывший сотрудник ИСЭП АН СССР } \\
\text { и Института социологии РАН. Исследовательские интересы: гражданское общество, } \\
\text { этничность, миграции, повседневность, социальная структура, качественные методы } \\
\text { в социологии. }\end{array}$ & 2 \\
\hline $\begin{array}{l}\text { Waldinger R. Immigrant Enterprise: A Critique and Reformulation // Theory and Society, vol. 15, } \\
\text { no 1/2, Special Double Issue: Structures of Capital. (Jan., 1986), pp. 249-285. } \\
\text { Roger Waldinger - BA in History, PhD in Sociology, Professor of Sociology (UCLA). }\end{array}$ & 2 \\
\hline $\begin{array}{l}\text { Light I. (1984) Immigrant and Ethnic Enterprise in North America // Ethnic and Racial Studies, } \\
\text { vol. 7, no 2, pp. 195-216. } \\
\text { Ivan Light - PhD in Sociology. Professor Emeritus in Sociology (UCLA). }\end{array}$ & 2 \\
\hline Смирнова Т.Б. (2002) Немцы Сибири: этнические процессы. Омск: Русинко. & 6 \\
\hline $\begin{array}{l}\text { Light I. (1986) Ethnicity and Business Enterprise // Making It in America (eds. Stolarik M., } \\
\text { Friedman L.), Toronto: AUP, pp. 13-32. }\end{array}$ & 2 \\
\hline $\begin{array}{l}\text { Light I., Karageorgis S. (1994) The Ethnic Economy // The Handbook of Economic Sociology } \\
\text { (eds. Smelser N., Swedberg R.), Princeton, pp. 646-671. }\end{array}$ & 7 \\
\hline $\begin{array}{l}\text { Воронков В.М., Освальд И. (ред.) (1998) Конструирование этничности: Этнические общины } \\
\text { Санкт-Петербурга. СПб. }\end{array}$ & 6 \\
\hline Томпсон П. (2003) Голос прошлого. Устная история. М.: Смысл. & 4 \\
\hline $\begin{array}{l}\text { Бредникова О., Паченков О. (2000) Этничность «этнической экономики» и социальные сети } \\
\text { мигрантов // Труды Центра независимых социологических исследований. Выпуск 8. } \\
\text { Этничность и экономика / Этничность и экономика. Сб. статей по материалам } \\
\text { международного семинара (Санкт-Петербург, 9-12 сентября 1999). СПб. Выпуск 8. С. 47-54. } \\
\text { Олег Вячеславович Паченков - окончил исторический факультет СПбГУ и } \\
\text { магистерскую программу Европейского Университета в СПб, к.с.н., директор } \\
\text { Центра прикладных исследований Европейского университета в Санкт-Петербурге. } \\
\text { Бывший сотрудник ЦНСИ. Исследовательские интересы: социология/антропология } \\
\text { повседневности, социология/антропология города, этническая миграция, } \\
\text { меньшинства и этническое предпринимательство, качественная методология в } \\
\text { социальных науках. }\end{array}$ & 8 \\
\hline
\end{tabular}

Примечание. Подчеркиванием выделены ключевые слова, помогающие сформулировать название таблицы. Серым цветом выделены строки, соответствующие названию таблицы.

Примером идентифицированной группы цитирований является полученная в ходе анализа Шилдта итоговая таблица, или плотная сеть (таблица 3). В строки таблицы, помимо краткого библиографического описания источников и количества их цитирований, помещены также вспомогательные данные, использованные в процессе идентификации.

Такая же модель построения таблиц использована для идентификации групп цитирований, полученных остальными методами. В тех случаях, когда числовые 
значения были ниже введенных критериальных значений в 5 публикаций, 50 цитирований для публикаций в одной таблице или не достигали половины от всех публикаций и цитирований в таблице, они выделялись полужирным шрифтом. Индексные обозначения и соответствующие им названия таблиц (т.е. групп цитирований) были организованы в большие сводные таблицы ${ }^{12}$.

Рассмотрение всей совокупности полученных тремя методами идентифицированных групп цитирований ${ }^{13}$ показывает, что заметная часть одних и тех же публикаций попадает в таблицы, полученные разными методами. Такие публикации можно назвать пересекающимися, а таблицы с пересекающимися публикациями целесообразно объединять в крупные формирования ${ }^{14}-$ модули (далее $\mathrm{Mo}^{15}$ ), которые в свою очередь образуют более крупные образования - блоки (далее Б). Все группы цитирований отнесены к тому или иному блоку. Сами блоки определялись мною субъективным образом, но при этом пересекающиеся таблицы, как уже было сказано, определялись по количественному критерию. Далее в тексте показаны и пересекающиеся группы цитирований, и группы-изоляты (сепаратные) в составе блоков ${ }^{16}$.

Ниже приведены описания всех выделенных блоков, причем в ряде случаев модули внутри блоков не прослеживаются. В данном описании используются результаты не только для порога 2, но и для порогов 4 и 7.

\section{Б1. Советская и российская этнология как научная дисциплина}

Пересекающиеся группы цитирований. Порог 2. К00993: 15/27(43/72) «Этнографическая наука в СССР»; C1353: 14/21(35/57) «Теория и практика советской этнографии»; Г53: 33/60(81/158) «История и теория этнологии и антропологии»; К04580: $5 / 7(7 / 13)$ «Влияние Ф. Боаса на советскую этнологию».

Сепаратная группа цитирований (далее СГЦ) внутри Б1. Порог 2. Г246: 9/14(24/32) «Советское и современное российское этнологическое образование».

\section{Б2. Восточнославянская этнология и фольклористика}

В данный блок попадает довольно много таблиц, причем заметная их часть пересекается не только на пороге 2, но и на пороге 4 и пороге 7.

Mo $A$.

Пересекающиеся группы.

Порог 2. К01907: 109/119(484/539) и Г2: 475/682(1865/2545) «Восточнославянская этнология и фольклор»; К01319: 14/23(51/89) «Русская свадьба и похороны»; Г29: 47/95(159/289) «Ритуал, обряд, семиотика культуры»; К02343: 6/7(17/23)

\footnotetext{
12 В связи с ограниченностью печатной площади приходится излагать их содержание описательно.

13 Далее термины «группа публикаций» и «таблица» используются как синонимы.

14 О пересекающихся таблицах целесообразно говорить, когда в таблице, состоящей из меньшего количества публикаций, не менее четверти всех публикаций попадает и в таблицу, имеющую большее количество публикаций. В таблицах из равновеликого числа публикаций действует этот же критерий, определенный эмпирическим путем. При этом пересекающихся публикаций должно быть не меньше трех.

15 Список сокращений: Б - блок; Г - группирование; $\mathbf{K}$ - кластер; Мо - модуль; П - порог; СГЦ - сепаратная группа (или группы) цитирований; Ш - плотная сеть.

16 К сепаратным группам публикаций отнесены и случаи, когда на основе ссылок из одного набора цитирующих статей вычленяются кластеры, группирования или плотные сети с одинаковым или близкими по тематике названиями. В таких случаях значимых пересечений с другими группами цитирований, полученными на другом наборе цитирующих статей, не наблюдается.
} 
«Советские праздники и ритуалы»; Ш765: 10/18(45/81) «Народные игры»; С795: 8/13(40/72) «Народная медицина и гигиена»; Ш1022: 11/20(36/61) «Русское народное поэтическое творчество»; К01102: 24/45(107/177) «Русская народная религиозность»; Ш599: 11/12(64/96) «Русский фольклор как исторический источник»; К06582: 10/15(31/61) «Сани в русской культуре»; К00936: 28/43(226/307) «Духовная культура русских»; К04418: 4/6(8/12) «Русский Север»; К02058: 5/5(11/11) «История Древней Руси»; Ш578: 6/9(34/64) «Культурный ландшафт в русском фольклоре»; Ш287: 7/10(23/61) «Восточнославянские заговоры и гадания»; Ш404: 6/11(31/95) «Славянская мифология»; Ш498: 6/11(47/60) «Русская обрядность»; Ш1102: 12/20(46/73) «Мифология финноязычных народов» ${ }^{17}$; К02582: 3/7(7/16) «Этнология вепсов» ${ }^{18}$; К01591: 29/36(159/207) «Славянская фольклористика»; К02376: 13/23(55/92) «Балто-славянские заговоры»; К01426: 4/8(8/22) «Русский фольклор о кладах»; К01550: 6/6(20/20) «Русская фольклористика»; К02759: 5/8(11/18) «Восточнославянские традиции, связанные со смертью»; К01111: 5/9(43/71) «Русская народная сказка».

Порог 4. К0178: 102/126(880/1081), Ш15: 15/24(128/186) и Ш59: 6/7(29/35) «Восточнославянская этнология и фольклор»; Ш58: 6/11(28/57) «Поэтические формы русского устного народного творчества»; К0165: 7/13(52/99) «Русская свадьба и похороны»; Ш3: 10/28(211/247) «Русские народные представления о природе»; К0165: 7/13(52/99) «Народная обрядность»; К0321: 3/5(36/48) «Семиотика фольклора»; Ш10: 12/24(107/202) «Русская мифология»; К0124: 11/20(66/118) и Ш45: 10/20(69/126) «Теория фольклора»; К0184: 6/15(50/108) «Русская народная сказка»; Ш48 3/6(13/34) «Русская свадебная обрядность»; К0152: 3/5(23/31) и Ш31 12/23(98/162) «Сакральное в восточнославянской этнологии и фольклоре»; К0124: 11/20(66/118) и Ш45: 10/20(69/126) «Теория фольклора».

Порог 7. К0364: 35/44(452/547), К0054: 33/68(415/814) и Ш10: 11/14(149/229); Ш34: 7/8(158/165) «Восточнославянская календарная обрядность»; К0365: 7/11(63/106) и Ш13: 6/11(56/106) «Восточнославянские заговоры и заклинания»; Ш10: 11/14(149/229) «Русская мифология».

Мо Б.

Пересекающиеся группы.

Порог 2. Ш761: 9/13(36/60) «Материальная культура сибирских старообрядцев»; К02723: 5/9(19/27) «Декоративно-прикладное искусство восточных славян»; Г71: 25/49(75/137) «Декоративно-прикладное искусство и народная архитектура восточных славян»; К02377: 5/6(10/13) «Скифо-сарматские знаковые системы».

Mo B.

Пересекающиеся группы.

Порог 2. Ш297: 5/9(35/50) «Русский вокальный фольклор»; Г488: 4/5(9/11) «Южнорусский музыкальный фольклор».

Мо $\Gamma$.

Пересекающиеся группы.

17 По тематике данная плотная сеть не должна была включаться в восточнославянскую совокупность, но 11 источников из нее попадают также в Г2: 475/682(1865/2545) «Восточнославянская этнология и фольклор» и больше ни в какие группирования или кластеры. Объяснить это можно тем, что специалисты по восточным славянам используют материал по финноязычным группам в сравнительных целях.

18 Ситуация с данным кластером аналогична предыдущей плотной сети: процитированные публикации пересекаются лишь с Г2. 
Порог 2. Ш968: 8/13(39/64) «Этнографическая семиотика»; К02680: 6/7(26/28) «Семиотика вещей»; Г158: 12/24(42/74) «Русская народная одежда и полотенца и их роль в обрядах».

Мо Д.

Пересекающиеся группы.

Порог 2. К02050: 15/22(86/120) и Г67: 25/50(103/171) «Русский героический эпос»; К02256: 8/8(32/32) «Севернорусский фольклор»; К01110: 5/8(14/27) «Севернорусские былины».

Порог 4. К0185: 6/10(31/50) «Русский героический эпос»; Ш6: 18/20(121/144) «Восточнославянский эпос»; Ш21: 7/14(42/80) и К0177: 6/13(30/74) ${ }^{19}$ «Русское устное народное творчество».

$\boldsymbol{M o} \boldsymbol{E}$. Пересекающиеся группы.

Порог 2. К02981: 7/14(20/38) «Русские народные представления о загробном мире»; Г92: 22/40(61/121) и К02583: 6/13(22/37) «Видения и представления о потустороннем мире и эсхатологические представления в русском фольклоре».

Мо Ж. Пересекающиеся группы.

Порог 2. Г99: 20/38(85/132) «Теоретическая фольклористика»; К02170: 4/7(16/22) «Воронежская школа восточнославянской фольклористики».

СГЦ внутри Б2. Порог 2. Ш1206: 14/20(37/62), Г146: 18/26(49/80) и К00536: 10/13(28/32) «Русские Сибири»; Г321: 6/9(16/35) и К02342: 6/10(16/32) «Русская народная одежда»; Ш1205: 10/16(30/58), Г170: 12/21(32/60) и Ш01230: 10/11(29/32) «Русский городской фольклор»; Г237: 6/15(15/40) «Русский анекдот»; К04307: 4/5(11/13) «Старообрядчество»; Г318: 8/10(22/26) «Детский фольклор»; Г442: 4/6(9/13) «Русские пословицы и поговорки»; Г435: 4/6(15/19) «Учебники и учебные пособия по русскому фольклору»; Г495: 4/5(8/10) «Русские травники и учебники»; Г212: 9/16(51/69) «Русская культура»; Г222: 9/16(28/44) «Этнография русских»; Г333: 5/9(19/28) «История Древней Руси»; Г162: 12/23(50/77) «Русская народная религиозность»; Г211: 9/16(43/57) «Теория фольклора».

Следующие СГЦ пересекаются только друг с другом, не имея значимых пересечений с другими группами: Ш557: 8/16(27/55) «Фольклорные жанры» и Г256: 7/13(29/43) «Русские легенды и предания»; Г139: 14/27(36/70) «Русский городской и лагерный песенный фольклор» и К02653: 3/6(7/14) «Русский песенный фольклор».

\section{Б3. Монголоведение и тюркология}

Пересекающиеся группы.

Порог 2. Ш575: 9/12(33/58) и Г252: 9/14(31/43) «Этнология калмыков»; К00446: 55/109(209/427) «Этнология и история народов монгольской группы»; Г103: 18/36(57/105) «Этнология монголоязычных народов»; Ш947: 9/17(46/80) «Бурятский шаманизм»; Г154: 13/25(48/82) «Этнология Бурятии»; Ш1082: 8/15(32/47) «Религия бурят».

Порог 4. Ш24: 5/9(24/48) «Этнология калмыков»; К0218: 8/8(45/45) «Этнология народов монгольской языковой группы»; Ш36: 5/9(29/55) «Этнология народов монгольской группы (преимущественно бурят)»; К0164: 13/19(81/130) «Скотоводческие народы Южной Сибири и Центральной Азии (тюрко-монголы)».

СГЦ внтури Б3. Порог 2. Г254: 9/14(18/30) «Эпос тюрко-монгольских народов».

19 Публикации данного кластера в равной степени пересекаются на пороге 2 с Г2: 475/682(1865/2545) «Восточнославянская этнология и фольклор». 


\section{Б4. Сибиреведение}

Mo $A$. Пересекающиеся группы.

Порог 2. Ш960: 14/22(51/83) «Этнография народов тунгусо-манчжурской группы»; Г241: 9/15(28/41) «История и этнология Восточной Азии».

Мо Б. Пересекающиеся группы.

Порог 2. К02698: 10/15(37/59) «Этнология и язык народов тунгусо-маньчжурской группы»; Ш1185: 11/16(35/65) «Этнология народов Северо-Восточной Азии»; К02556: 53/58(209/223) «Этнология народов Сибири»; Г4: 226/452(803/1421) «Сибиреведение (этнология + фольклор + история + археология + народное искусство + лингвистика)»; К02042: 10/16(41/80) «Этнология и язык якутов»; Ш764: 5/10(40/65) «Этнология якутов»; К00704: 5/5(11/11) «Этнография и фольклор колымского населения»; Ш1184: 10/17(31/61) «Юкагиры и метисные группы северо-востока Сибири»; К02557: 13/15(62/71) «Этнология Северо-Восточной Азии»; Г14: 97/158(304/470) «Сибиреведение»; К03045: 4/5(8/11) «История Тюменского края»; К02134: 6/9(33/44) «История Сибири»; Ш647: 9/14(20/42) «Этномузыкология» ${ }^{20}$.

Порог 4. К0150: 26/42(172/284) «Этнология Восточной Сибири (тунгусо-маньчжуры, якуты, юкагиры, палеоазиаты)».

Порог 7. К0062: 0062: 26/45(261/498) и Ш14: 9/15(96/151) «Этнология Сибири».

Мо В. Пересекающиеся группы.

Порог 2. К01419: 14/24(70/120) «Этнология Алтая»; Г150: 17/25(80/99) «Этнология народов Алтая (или этнография народов, говорящих на горно-алтайских языках)»; Ш596: 6/11(40/69) «Этнология тюрков Алтая и шорцев».

Мо $\boldsymbol{\Gamma}$. Пересекающиеся группы.

Порог 2. К04329: 4/7(12/20) «Этнология алтайцев»; Г157: 14/24(47/72) «Бурханизм»; Ш1233: 9/13(27/36) «Религиозные верования тюрков алтае-саянского региона» ${ }^{21}$

Порог 4. К0242: 5/9(32/58) и Ш9: 8/16(74/116) «Религия алтайцев».

СГЦ внутри Б4. Порог 2. Ш794: 10/19(37/74) «История Сибири»; Ш1892: 24/30(50/65), Г81: 26/43(73/116) и К01906: 31/41(75/102) «Деятельность В.И. Иохельсона»; Ш859: 10/18(31/54) и К00284: 10/15(26/43) «Ислам и мусульмане в Сибири»; и Г191: 6/19(13/51) «Сибирские татары»; Г446: 5/6(11/14) и К02374: 3/7(5/11) «Верования алтайцев»; К04472: 6/7(14/17) и Г348: 5/9(12/21) «Древнее и современное население плато Укок»; Ш1953: 40/77(82/156), Г39: 60/84(128/200) и К02842: 64/87(128/289) «Н.Ф. Катанов и его научное наследие»²2; Г330: 5/9(21/30) «Этнология эвенков и эвенов»; Г301: 6/11(16/26) «Этнология тюрок Алтая»; Г376: 4/8(9/17) «Этнология шорцев»; Г464: 3/5(6/13) «Малочисленные народы Севера и Дальнего Востока».

Порог 4. Ш65: 4/6(21/38) «Этнология Северо-Восточной Азии».

\section{Б5. Этнология народов уральской языковой семьи}

Пересекающиеся группы.

Порог 2. Ш1441: 8/16(31/55): «Этнография ненцев»; Г19: 73/140(294/499) и Ш1712: 22/27(67/86) «Этнология народов уральской языковой семьи» и К00703:

\footnotetext{
20 Хотя у этой сети имеется 8 пересечений с Г4, лишь 4 публикации имеют отношение к сибиреведению.

21 У этой сети равное количество публикаций пересекаются с Г157 «Бурханизм» и с Г25 «Шаманство и шаманизм».

22 Эти взаимопересекающиеся кластеры, плотная сеть и группирование с одинаковым названием образованы за счет ссылок к двум статьям Р.М. Валеева.
} 
55/76(238/317) «Этнология и фольклористика народов уральской семьи»; К00686: 6/6(23/23) «Этнология самодийцев»; С1142: 9/17(35/76) и К01924: 10/19(32/64) «Этнология коми»; К02800: 6/6(14/14) «Физическая антропологии народов СССР»23.

Порог 4. К0179: 22/28(144/180) и Ш2: 18/22(121/149) «Этнология народов уральской языковой семьи»; Г17: 15/19(95/120) «Этнология народов уральской языковой семьи или Этнология народов Западной Сибири»; Ш20: 8/13(39/76) «Этнология самодийцев».

Порог 7. Ш7: 7/12(82/126) и К0063: 7/11(72/105) «Этнология народов уральской языковой семьи».

СПГ внутри Б5. Порог 2. Г383: 5/7(16/20) «Этнология и фольклор карел».

\section{Б6. Этнология Поволжья}

Мо А. Пересекающиеся группы.

Порог 2. Ш699: 6/12(19/50) «Этнология чувашей»; Ш1791: 16/25(35/53), Г98: 22/38(55/94) и К02740: 15/24(35/53) «Конфессиональные процессы у чувашей».

Мо Б. Пересекающиеся группы.

Порог 2. К02065: 5/7(12/17) «Этногенез и этническая история удмуртов»; К01578: 5/7(15/17) «Удмуртская этнография и фольклор»; Г44: 35/70(120/205) и К01893: 18/31(56/90) «Этнология удмуртов»; Ш1043: 11/19(44/69) «Этнология удмуртов»; Ш1309: 14/23(39/61) «Этнология удмуртов»; Ш1522: 9/18(29/52) «Религиозные верования удмуртов».

Порог 4. К0428: 8/10(50/77), Ш43: 4/5(22/26) и Г39: 6/7(38/44) «Этнология удмуртов».

СГЦ внутри Б6. Порог 2. Г312: 7/10(15/24) и К01316: 7/9(15/22) «Этническая идентичность народов Башкортостана»; Г288: 6/11(20/32) и К04352: 5/9(18/28) «История и этнология татар».

\section{Б7. Этнология Средней Азии и Казахстана}

Пересекающиеся группы.

Порог 2. К03037: 5/6(13/15) «Этнология народов Таджикистана»; Г282: 6/12(19/34) «Памирские таджики».

СГЦ внутри Б7. Порог 2. Г430: 3/6(9/17) «Этнология казахов»; Г484: 5/5(10/10) «Социолингвистика Средней Азии»; Г431: 3/6(10/16) «Демография Казахстана».

\section{Б8. Кавказоведение}

Mo $\boldsymbol{A}$. Пересекающиеся группы.

Порог 2. Ш1504: 11/20(43/62) «Этнология адыгов»; Ш1959: 23/34(46/68) и Г63: 33/53(82/147) «Этнология убыхов» ${ }^{24}$, К00478: 53/86(152/281) «Этнология и история адыго-абхазских народов»; Г490: 4/5(13/16) «Этнология адыгов».

Порог 4. К0158: 8/12(43/61), С8: 18/23(84/109) и Г42: 18/24(83/116) «Этнология адыго-абхазских народов».

Мо Б. Пересекающиеся группы.

Порог 2. К00570: 3/6(10/17) «Этнология и фольклор адыгов»; Ш784: 6/15(20/56) «Духовная культура адыгов»; Г183: 15/26(34/63) «История и традиционная культура Северного Кавказа».

23 В этом кластере три публикации посвящены физической антропологии народов угорской и финской языковых групп.

24 Группы цитирований по убыхам образованы в основном благодаря ссылкам в статьях М.Г. Хафизовой. 
Мо В. Пересекающиеся группы.

Порог 2. К06714: 5/6(14/16) «Этнология ногайцев»; Г227: 9/15(35/57) «Традиционный кавказский этикет».

Мо Г. Пересекающиеся группы.

Порог 2. Г32: 47/91(191/293) «История и этнология Дагестана» и К01468: 19/36(71/135) «Обычное право и брачные обычаи на Северо-Восточном Кавказе»; Ш955: 8/15(33/53) «Прошлое народов Дагестана (история + археология + этнология)»; К02069: 6/14(15/37) «История Дагестана»; Г200: 13/18(37/47) «История Северного Кавказа»; К01317: 25/36(82/112) «История Дагестана»; Г86: 29/42(82/115) «Этнология Северо-Восточного Кавказа»; К04309: 3/5(7/11) и Г78: 26/44(81/154) «Горские евреи и таты».

Порог 4. Ш26: 15/24(88/172), 16/32(91/182) и Ш30: 7/11(36/65) «Этнология Дагестана». Порог 7. К0245: 5/7(37/59) и Ш6: 5/7(37/60) «Этнология Дагестана».

Мо Д. Пересекающиеся группы.

Порог 2. Г70: 34/50(113/148) «Ислам в Российской империи, СССР и СНГ»; К02757: 6/9(16/22) «Ислам на Северном Кавказе».

СГЦ внутри Б8. Порог 2. ГЗ10: 8/10(20/24) и К04416: 3/6(9/15) «История Армении и армян»; К02068: 5/5(11/11) и Г423: 4/6(9/13) «Суфийский ислам в Дагестане»; К00898: 12/22(61/98) «Этнология народов Северного Кавказа»; Г148: 15/26(34/63) «История, этнография, фольклор адыго-абхазов»; Ш500: 4/7(22/50) «Этнология осетин».

\section{Б9. Американистика}

Пересекающиеся группы.

Порог 2. К00833: 59/80(136/197) «Этнология Америки»; К01101: 8/9(17/19) и Г210: 14/17(29/35) «Российская этнология коренного населения Америки»; Г441: 6/6(12/12) «Исследования Аляски».

Б10. Сепаратные группы цитирований, имеющие в основе работы Ю.Е. Березкина Порог 2. Ш1963: 22/28(53/68) «Фольклористика»; Ш1922: 40/51(114/147) «Фольклористика»; Ш1969: 25/40(51/82) «Мифология американских индейцев»; С1965: 34/56(77/124) «Мифология американских индейцев»; К03981: 18/25(48/80) «Фольклористика»; К01438: 67/106(263/438) «Фольклористика»; К01590: 49/56 (153/170) «Сравнение фольклорных сюжетов Америки и Сибири».

Как уже отмечалось выше, данные группы цитирований объединены в один блок, поскольку они образованы в результате того, что (кроме Ю.Е. Березкина) очень мало исследователей ссылается на собранные здесь публикации.

\section{Б11. Этнографическое музееведение}

Пересекающиеся группы.

Порог 2. Г15: 134/151(213/424) и К01252: 77/141(206/386) «Этнографическое музееведение»; Г166: 15/23(30/46) «Этнографическое музееведение»; Г302: 9/11(23/27) и К04387: 9/10(23/25) «Батакские коллекции МАЭ»25; Г370: 5/8(11/20) «Этнографическое музееведение».

Порог 4. К0256: 8/16(46/90) «Этнографические музеи»; С15: 16/26(76/147) «Музейные коллекции и русские географические экспедиции XVIII-XIX вв.».

Порог 7. С1: 3/5(23/40) «МАЭ (Кунсткамера)».

25 Группирование и кластер образовались за счет цитирований из статей Е.В. Ревуненковой. 
Б12. Системы родства и первобытное общество

Мо A. Пересекающиеся группы.

Порог 2. К02263: 14/20(45/67) «Компаративистика (сравнительно-историческое языкознание)»; Г13: 80/160(239/434) «Системы родства и отношения подшучивания»; Ш928: 12/19(40/54) «Системы родства» ${ }^{26}$; К03794: 5/8(12/20) «Монгольская система родства»; К03007: 12/21(34/53) «Системы родства»; К03006: 11/21(28/55) «Первобытное общество»; К04311: 5/5(10/10) «Этнология народов науа».

Порог 4. К0202: 9/15(48/91) и Г31: 8/15(39/72) «Системы родства»; C17: 9/17(80/125) «Этнография доклассовых и раннеклассовых обществ».

Мо Б. Пересекающиеся группы.

Порог 2. Г80: 23/43(62/108) «Антропология власти и переход к раннеклассовому государству» и С931: 10/20(30/60) «Раннее государство»; К01491: 7/12(19/31) «Раннее государство».

СГЦ внутри Б12. Порог 2. К02732: 9/13(38/68) «Мировоззрение первобытного человека» и Г132: 15/29(72/112) «Особенности мышления в досовременных обществах и этнического мышления»; Г116: 14/34(43/100) и К06620: 5/7(17/27) «Первобытная и раннеклассовая история (в основном по работам Ю.И. Семенова)»; Г208: 9/17(27/41) и К04854: 9/12(25/31) «Современные охотники-собиратели Африки».

\section{Б13. Проблематика социокультурной антропологии}

Mo A. Пересекающиеся группы.

Порог 2. Ш1573: 21/23(50/57) и К01942: 6/11(12/26) «Пространство и время в традиционной культуре»; Г48: 40/66(124/192) «Культурные модели мира (включая представления о пространстве и времени)».

СГЦ внутри Б13. Порог 2. К02530: 5/5(23/23) «Исследования культуры»; C1387: 17/29(46/76), Г105: 19/36(52/95) и К02269: 16/31(47/83) «Индийские касты»; К02360: 5/8(26/50) «Этнография детства»; Г286: 6/11(16/28) и К02260: 4/6(7/13) «Феномен попрошайничества»; Г347: 6/9(16/22) и К04310: 4/5(8/10) «Юридическая антропология»; Г277: 9/12(21/28) и К04302: 4/5(8/10) «Правовые проблемы индигенных народов»; Гз37: 5/7(10/17) «Антропология как дисциплина»; ГЗ35: 5/8(10/18) «Исследование сновидений».

\section{Б14. Англоязычная антропология}

Пересекающиеся группы.

Порог 2. Г61: 30/54(85/160) «Англоязычная антропология»; К02987: 4/5(10/13) «Англоязычная антропология».

\section{Б15. Этническая экология}

Порог 2. Г115: 18/34(60/100) и К01068: 16/32(53/101) «Этническая экология».

Порог 4. К0320: 4/8(19/36) и Г55: 3/5(16/25) «Этническая экология» и C28: 7/12(32/64) «Этническая экология и физическая антропология».

Б16. Этнографическое религиоведение

Mo $\boldsymbol{A}$. Пересекающиеся группы. 
Порог 2. Ш1308: 13/16(50/57) «Религия обских угров»; К06406: 4/7(10/18) «Религия обских угров»; Г49: 48/62(154/196) «Религиозные представления обских угров»; К01082: 14/28(48/89) «Этнология обских угров» и Ш1146: 10/17(36/66) «История обских угров»; Ш1621: 14/24(35/69) и К01081: 15/25(55/102) «Этнология обских угров».

Порог 4. К0200: 14/26(86/162) и Ш16: 12/18(63/102) «Этнология обских угров» и К0159: 28/55(174/337) «Ранние формы религии» ${ }^{27}$.

Мо Б. Пересекающиеся группы.

Порог 2. Ш263: 4/9(33/62) «Этнология тувинцев»; Ш1744: 11/20(29/54) «Шаманизм»28; К02347: 5/7(11/15) «Шаманизм»; Г25: 55/106(189/342) «Шаманство и шаманизм»; К02265 32/64(132/245) «Шаманство и шаманизм».

Порог 4. Ш4: 11/18(68/129) и Г23: 9/13(65/79) «Шаманство и шаманизм»; К0159: 28/55(174/337) «Ранние формы религии» ${ }^{29}$.

Мо B. Пересекающиеся группы.

Порог 2. К02302: 10/18(25/54) «Среднеазиатская религиозная обрядность (включая праздники)»; К04167: 4/6(8/14) «Религиозные представления народов Нижнего Поволжья»; К04164: 12/22(47/91) «Пережитки доисламских верований у мусульманских народов»; С1918: 13/29(27/56) «Религиозные верования тюрков Нижнего Поволжья»; C1396: 9/11(38/43) «Доисламские верования и их пережитки в Средней Азии»; К01952: 16/26(60/96) «Ислам и доисламские верования у мусульманских народов»; С641: 8/13(25/51) «Одежда мусульман Средней Азии и Казахстана»; Г28: 55/99(183/316) «Ислам на территории Российской империи и СССР (в основном у тюркских народов)».

Порог 4. К0241: 8/13(53/80), К0243: 7/11(31/53) и Ш7: 10/21(67/134) «Ислам и доисламские верования в Средней Азии и Казахстана»; Г26: 11/21(68/123) «Исламоведение».

Порог 7. К0244: 5/8(54/72) и Ш3: 5/10(47/92) «Ислам и доисламские верования в Средней Азии и Казахстана».

Мо Г. Пересекающиеся группы.

Порог 2. Г88: 22/41(83/155) «Ранние формы религии и их пережитки»; К06664: 14/34(50/112) «Почитание животных и обряды, связанные с животными».

СГЦ внутри Б16. Порог 2. Ш209: 7/10(43/54) и Г448: 5/5(15/15) «Народное православие».

\section{Б17. Этнос и этничность}

Mo $\boldsymbol{A}$. Пересекающиеся группы.

Порог 2. Ш1360: 11/15(33/50) «Теория этноса С.М. Широкогорова»; К00992: 12/21(52/94) «Этнос и этничность»; К01925: 9/11(33/37) «Советские теории этноса и нации»; Г9: 101/202(362/623) «Этничность, этнические общности, учет населения по этническому составу»; К01998: 4/8(10/20) «Аланы и сарматы»; К02754: 11/15(96/136) «Теория этноса и ее критика».

Порог 4. К0303: 13/21(115/174) «Теория этноса»; Г7: 10/11(92/96) «Теория этноса и ее критика».

Порог 7. К0151: 10/17(119/192) «Теория этноса».

Мо Б. Пересекающиеся группы.

27 Данный кластер также пересекается с группами цитирований в следующем модуле Ш4 и Г23.

28 У этой сети заметное число цитирований пересекается с Г4 «Сибиреведение».

29 Кластер попадает также в предыдущий модуль. 
Порог 2. К02382: 15/26(56/95) «Теория Гумилева и ее критика»; Г27: 52/101(219/376) «Евразийство, теория Л.Н. Гумилева и их критика»; Ш56: 4/6(10/53) «Этнология хакасов».

Порог 4. К0135: 4/5(19/23) и Г9: 6/11(44/66) «Теория Л.Н. Гумилева»; Ш23: 7/12(48/88) «Теория Л.Н. Гумилева и ее критики».

Порог 7. К0184: 20/41(301/597) «Философия».

СГЦ внутри Б17. Порог 2. Ш541: 6/11(27/69) «Этничность и этническая идентичность».

Б18. Нации, национализм, этнонациональные отношения

Mo A. Пересекающиеся группы.

Порог 2. К01481: 6/12(39/73) «Национализм»; К02718: 13/18(70/107) «Нации, национализм, nationalism studies ${ }^{30} » ;$ К02719: 7/12(39/70) «Этническая идентичность и этнические границы»; К02598: 12/20(104/143) «Нации, национализм, этнонациональная политика»; К06794: 6/13(13/30) «Этнонациональные и этноязыковые проблемы в посткоммунистической Восточной Европе»; К02916: 7/11(12/26) «Этнонациональные процессы у российских карел»; Ш1160: 11/14(42/51) «Этнонациональная история России и СССР»; С419: 7/13(29/62) и К02708: 6/7(7/18) «Современные этнические процессы у коми»; К03786: 5/8(12/18) «История евреев в России»; К02709: 6/9(26/36) «Гуманитарная география»; К02394: 4/5(9/11) «Историческая память».

Порог 4. С72: 5/9(36/55) «Национализм»; К0188: 21/41(198/367) «Нации, национализм, этнонациональная политика»; Г3: 16/26(165/217) «Этничность, национализм, этнонациональная политика»; С32: 8/13(55/97) «Этничность и национализм».

Порог 7. К0150: 14/22(208/349) «Этничность, национализм, этнонациональная политика)»; Ш27: 12/12(213/213) «Этничность, национализм, этнонациональная политика».

Мо Б. Пересекающиеся группы.

Порог 2. К03965: 3/5(14/22) «Этнонациональные конфликты»; К04212: 4/5(10/14) «История корейцев в России»; Г100: 19/38(77/118) «Межэтнические отношения и этнонациональная политика».

Мо В. Пересекающиеся группы.

Порог 2. Г62: 34/53(85/146) «Этнонациональная и этнорелигиозная политика в Российской империи и РФ» и К01533: 19/33(53/106) «Ислам и политика российского самодержавия»; К06706: 5/8(12/19) «Этнология казахов».

Мо Г. Пересекающиеся группы.

Порог 2. Ш740: 9/11(48/58) «Миграции, мультикультурализм, толерантность»; Г114: 16/34(70/140) «Этнонационализм (включая имперский) и этнонациональная политика»; К04213: 4/5(8/14) «Русский имперский национализм».

СГЦ в Б18. Порог 2. Г498: 4/5(8/10) и К04308: 4/5(8/10) «Формирование гражданского общества в Латвии»; Ш1166: 12/16(39/55) «Этнонациональная политика»; Г405: 4/7(10/16) «Этнополитология».

Б19. Этносоциология, этнопсихология, этническая идентичность Mo A. Пересекающиеся группы.

30 Термин nationalism studies в англоязычной литературе применяется к междисциплинарной исследовательской области по изучению национализма и смежных вопросов. 
Порог 2. Ш326: 8/10(69/74) «Психология межэтнических отношений»; К02599: 8/9(24/26) «Этнопсихология»; Г65: 26/51(120/201) «Этническая социология и этническая психология».

Мо Б. Пересекающиеся группы.

Порог 2. К00481: 4/8(33/56) «Этническая психология»; Г340: 5/9(20/29) «Этнопсихология»; К04179: 4/5(17/19) «Национальная и этническая идентичность».

СГЦ в Б19. Порог 2. К03056: 8/9(102/135) «Этичность и этносоциология»; Ш584: 7/10(33/59) «Связь религиозной и этнической принадлежности с экономическим поведением»; Ш530: 9/14(27/50) и К02496: 5/5(15/15) «Этническая экономика и этническое предпринимательство»; Ш986: 9/16(30/59) «Этническое предпринимательство»; К04724: 3/5(12/17) «Этносоциология»; Г121: 18/33(90/126) «Этносоциология»; К04415: 4/6(8/13) «Межэтнические отношения на Украине»; Г235: 9/15(38/54) «Исследования этнической идентичности»; К00202: 9/18(29/51) «Межэтническая напряженность, этнические предубеждения и конфликты».

\section{Б20. Отдельные этносы и диаспоры}

Мо А. Пересекающиеся группы.

Порог 2. К01086: 5/6(17/19) «Русские диаспоры»; К02634: 3/6(6/10) «История Переславля-Залесского»; К04534: 7/11(21/57) «Примордиализм/конструктивизм в понимании этничности»; Г12: 81/162(307/570), К01608: 8/15(55/128), К00681: 8/9(31/33) и Г120: 19/33(70/111) «Диаспоры».

Порог 4. Ш18: 10/17(54/94), Г2: 20/35(146/225), Ш47: 3/8(14/41), К0176: 6/7(27/34) «Диаспоры»; К0302: 12/22(70/142) «Диаспоры и этнические меньшинства»; Ш27: 7/12(31/59) «Русскоязычные диаспоры».

СГЦ в Б20. Порог 2. К04473: 4/8(8/19) и Г287: 6/11(13/30) «Этнографическая иудаика»; К02564: 10/18(28/55) и Г135: 17/28(43/78) «Изучение ашкеназийского еврейства»; Г379: 6/7(12/15) «Евреи в Российской империи»; Г429: 6/6(12/12) «Идентичность постсоветских евреев»; Г164: 14/23(40/60) и К01088: 9/16(24/39) «Российские немцы»; Г165: 19/23(37/49) и К01642: 9/17(18/34) «Баски и баскский язык»; Г203: 3/18(28/40) и К00765: 10/16(22/34) «Мигранты из Северной Африки (беры) во Франции»; Г186: 13/19(28/43) и К01588: 6/8(14/18) «История и культура японцев»; Г477: 3/5(6/10) «Этнология айнов»; Г192: 11/19(26/46) и К00924: 5/5(13/13) «Китайцы на Дальнем Востоке России».

\section{Б21. Прочее}

Mo $A$. Пересекающиеся группы.

Порог 2. Г90: 26/41(102/163) и К04599: 8/10(40/45) «Визуальные исследования».

Порог 4. Ш33: 9/13(52/76) «Семиотика социальной коммуникации» и Г46: 7/9(40/44) «Семиотика социальной коммуникации».

Порог 7. Ш25: 5/6(53/64) «Семиотика социальной коммуникации».

СГЦ в Б21. Порог 2. Ш678: 8/13(8/31) «Образ трикстера в фольклоре»; Г331: 5/9(16/25) «Культурная география»; Г367: 6/8(13/19) «Народные спортивные единоборства»; Г304: 7/10(31/40) «Исследования детства»; Г465: 4/5(9/15) «Похоронное дело и русская похоронная обрядность»; Г495: 4/5(8/10) «Русские травники и лечебники»; Ш474: 4/8(11/50) и Г482: 4/5(9/12) «Этнопедагогика»; Г64: 26/51(87/155) «Миграция»; Г329: 5/9(11/26) «Социолингвистика»; Г455: 3/5(14/18) «Социолингвистика»; Г218: 8/16(37/54) «Традиционная культура народных низов»; Г459: 4/5(8/10) «Массовая (народная) культура». 


\section{Обсуждение и выводы}

Как уже отмечалось в начале статьи, невозможно полностью уйти от авторских субъективных моментов. Во-первых, это проявляется при формировании выборки, касающейся и временного интервала, и самих журналов. Во-вторых, при обработке матрицы возможны ошибки, связанные со сложностью многочасовой концентрации внимания. В-третьих, на результаты влияет выбор методов количественного анализа данных. В-четвертых, субъективность проявляется при эмпирическом выборе количественных критериев для идентификации таблиц. В-пятых, сложно добиться идеального соответствия названия таблиц, приписываемых им ярлыков их содержанию. Наконец, невозможно избежать субъективности исследователя при группировке идентифицированных таблиц в блоки и модули. Тем не менее количественные методы при правильной процедуре работы с ними позволяют снизить степень субъективности в отличие от качественных методов, когда субъективность исследователя вообще не сдерживается никакими формализованными процедурами.

Интересно сравнить результаты использования трех методов работы с социтированиями между собой, а также сопоставить их с анализом статей из журнала «Этнографическое обозрение», проведенного С.В. Соколовским [Соколовский 2003] $]^{31}$. Следует отметить, что в ходе работы с социтированиями возникает затруднение при попытке понять, что именно в полученных результатах является собственно исследовательской областью: блок, модуль, пересекающиеся группы цитирований, представленные всеми использованными методами (т.е. кластером, группированием и плотной сетью) или даже одна группа цитирований, сформированная любым из использованных методов. Группа цитирований - это результат применения одного из методов, но, видимо, такого результата в виде таблицы не совсем достаточно для того, чтобы говорить о наличии исследовательской области. Скорее, здесь мы имеем место с проблемной ситуацией. Вполне очевидно, что об области можно говорить, когда есть пересечение нескольких таких групп, причем хотя бы некоторые из них должны соответствовать введенному критерию наличия пяти публикаций, процитированных в совокупности не менее 50 раз. Дополнительным аргументом в пользу отнесения нескольких групп цитирований на пороге 2 к исследовательской области является наличие у них пересечений с порогом 4 или 7. Тем не менее надо быть готовым к тому, что будет оставаться какое-то число спорных случаев. Прояснить ситуацию до конца, как это обычно бывает в социологии, могут только многочисленные репликации исследования на сходном материале за разные временные промежутки.

В ходе обсуждения результатов представленного исследования необходимо представить схему когнитивной структуры российской этнографии, как она видится С.В. Соколовскому. В своей работе он приводит сводку статей, опубликованных в «Этнографическом обозрении» за 25 лет, где размещает их в соответствии с некоторой выстроенной концептуальной схемой. Она начинается с не имеющей

\footnotetext{
31 При этом следует учитывать различие в качественном и количественном подходах: у С.В. Соколовского во внимание принимаются даже единичные публикации, а в предложенном исследовании важно присутствие заметного количества публикаций со сходной тематикой.
} 
общего заголовка группы статей по наиболее общей теоретической тематике [Соколовский 2003, с. 23]. Затем следуют теоретические рубрики туры», «Теория этноса и этничности», «Теоретические дискуссии о предмете дисциплины и междисциплинарных границах», «Типологизация, классификация, таксономия», «Теория первобытности» [Соколовский 2003, с. 23-26]. Далее представлены большие рубрики, каждая из которых имеет сложное внутреннее членение: «Физическая (биологическая) антропология», «Культура», «Этнографические исследования общества» и «Фольклористика» [Соколовский 2003, с. 26-44]. После этого помещен значительный набор разрозненных областей: «Ономастика (этнонимика, топонимика)», «Этнорелигиоведение», «Музееведение», «Источниковедение», «Палеография», «Историография этнографии и социальной (культурной) антропологии», «Этноэкология», «Хозяйственно-культурные типы и традиционный образ жизни», «Этническая история (этноэкологические сюжеты)», «Этносоциолингвистика», «Этнопсихология», «Этногендерная проблематика», «Синтетические этнографические описания народов и меньшинств», «Сравнительные региональные исследования» и «Публицистика, поэзия, нетрадиционные жанры» [Соколовский 2003, с. 44-53].

Теперь перейдем к результатам настоящего исследования. В Б1 все три вида количественного анализа указывают на существование в современной российской этнологической науке исследовательской области, которая занимается осмыслением истории собственной дисциплины, а также пытается определить наиболее общие закономерности, описывающие сферу ее интересов (Г246 в эту область не входит). В статье С.В. Соколовского историография [Соколовский 2003, с. 47-50] отделена от общих этнологических теорий [Соколовский 2003, с. 23-26].

Принципиальные различия между двумя предложенными схемами проявляются в исследовательской проблематике, которую можно назвать этнологической регионалистикой. В данной статье она представлена в блоках 2-9, у С.В. Соколовского - лишь в двух небольших рубриках: «Синтетические этнографические описания народов и меньшинств» и «Сравнительные региональные исследования». Остальные работы по описанию этносов и регионов у него оказались рассредоточены по множеству других рубрик. Самым большим блоком в настоящем исследовании является «Восточнославянская этнология и фольклористика», а самый большой модуль (А) имеет одноименное с блоком название. Внутри модуля также имеются крупные группы цитирований (кластеры и группирования) с таким же названием, причем на всех трех порогах. Плотной сети с таким названием нет, но зато есть множество сетей, группирований и кластеров с восточнославянской тематикой, ссылки в которых пересекаются во всем этом наборе групп цитирований и на пороге 2, и на более высоких порогах. Недостижение установленных в работе

\footnotetext{
32 К сожалению, в данной схеме отсутствуют четкие определения характера выделяемых автором групп статей. Описывая их, С.В. Соколовский использует термины «область», «предметная область», «раздел», «подсистема», при этом термин «область» у него чересчур многозначен. Иногда он применяется для обозначения того, что традиционно понимается как отдельная наука (например, физическая антропология [Гинзбург 1963, с. 3]) или самостоятельная отрасль науки (например, фольклористика [Азадовский 2013, с. 68], иногда более узко, как некое подразделение внутри этнологии. В одном случае областью названо сразу несколько весьма различающихся между собой таксонов: «исследования общества, этносоциология, социальная антропология и этнодемография» [Соколовский 2003, с. 6]. Для простоты в дальнейшем выделяемые С.В. Соколовским группы статей будут называться рубриками, тем более что он сам использует этот термин (например, [Соколовский 2003, с. 5]).
} 
количественных критериев значимости у десяти групп цитирований компенсируются за счет их численности и служит дополнительным аргументом в пользу того, что восточнославянская этнология и фольклористика являются единой исследовательской областью, в отличие от схемы С.В. Соколовского, которая помещает статьи по материальной и духовной культуре всех народов (славян, тюрок, цыган и т.д.) в рубрику «Культура» [Соколовский 2003, с. 28-30], а статьи по фольклору опять же без учета этнической специфики - в рубрику «Фольклористика» [Соколовский 2003, с. 42-44].

Мо Б нельзя назвать исследовательской областью, поскольку К02723 и К02377 не достигают установленных критериев, а последний имеет высокую степень пересечения с Г71 только из-за своих небольших параметров. Не являются исследовательскими областями и Мо В и Мо Г, а вот Мо Д исследовательской областью считать можно. Хотя на пороге 2 две группы цитирований из четырех здесь не соответствуют критериям, зато есть пересечения с несколькими группами на пороге 4. Выбирая название этой области между «Русским героическим эпосом» и «Северно-русским фольклором», предпочтение было отдано первому, поскольку оно охватывает большее количество таблиц. Все остальные модули и сепаратные группы цитирований в этом блоке можно на данном этапе не принимать во внимание либо из-за несоответствия критериальным параметрам, либо ввиду отсутствия значимых пересечений с другими группами цитирований.

В Б3 можно было бы ожидать наличие отчетливо выраженных исследовательских областей по монголоведению и тюркологии, но в действительности есть только область «Монголоведение». Тюркские материалы здесь не дают самостоятельных групп цитирований: видимо, для исследователей тюркоязычных народов важнее не чисто этнокультурная проблематика, а связь тюркской этничности с исламом или особенностями региона проживания, что будет показано далее.

В Б4 самым большим является Мо Б, который можно определить как «Этнология Сибири», что совпадает с названием блока. Но при этом, как видно из названий таблиц на пороге 2 , есть заметное тяготение к территории Восточной Сибири. Это подкрепляется тем, что самая большая в этом блоке на пороге 2 таблица Г4 коррелирует с таблицей К0150 «Этнология Восточной Сибири (тунгусо-маньчжуры, якуты, юкагиры, палеоазиаты)». Два модуля относятся к этнологии Алтая, оба можно считать исследовательскими областями, поскольку в них ни одна из групп цитирований не основана на ссылках лишь к одной статье. Различия между ними в том, что если Мо В описывает общую этнологию тюрков Алтая, то Мо Г в большей степени сфокусирован на их религии, причем ссылки из одной таблиц в последнем, а именно Ш1233, в равной степени связана и с этим модулем, и с таблицей Г 25 «Шаманство и шаманизм» из Б16 «Этнографическое религиоведение».

В отличие от предыдущего блока, Б5 состоит из более связанных между собой таблиц, которые в совокупности, за исключением Г383, образуют одну совпадающую с названием всего блока исследовательскую область «Этнология народов уральской языковой семьи», охватывающую в основном обских угров, самодийцев, а также коми. Интересно, что удмурты в состав этой области не входят, они образуют самостоятельную исследовательскую область (Мо Б в Б6). Таким образом, можно говорить, что российское сибиреведение в настоящее время состоит 
из двух больших направлений: этнологии Западной Сибири с акцентом на обских уграх и самодийцах, а также соседних с ними коми и этнологии Восточной Сибири и Дальнего Востока. Как и удмурты, самостоятельную исследовательскую область образуют и чуваши (Мо А в Б6), причем в чувашской этнологии исследователей более всего привлекают этноконфессиональные сюжеты.

«Этнология Средней Азии и Казахстана» (Б7) представлена довольно скудным количеством групп цитирований, причем они не достигают установленных количественных критериев, и ссылки в них слабо пересекаются, поэтому исследовательской областью подобный набор таблиц назвать нельзя. Другие работы по этнологии этой историко-этнографической области попадают в этнографическое религиоведение (Мо В в Б16).

В отличие от предыдущего случая, в Б8 отчетливо различимы две исследовательские области: «Этнология адыго-абхазских народов» (Мо А) и «Этнология Северо-Восточного Кавказа» (Мо Г), при этом в последнем преобладают публикации по Дагестану.

Результаты исследования не подтверждают существования такой исследовательской области, как «Американистика». В Б10 пересекаются лишь К01101 и Г210, но эти группы цитирований не достигают заданных количественных критериев. Не помогают укреплению статуса американистики в качестве цельной области и статьи заведующего отделом этнографии Америки МАЭ РАН Ю.Е. Березкина, помещенные в самостоятельный Б11. Как уже отмечалось выше, особенностью работ этого автора является цитирование большого количество публикаций, особенно иностранных, на которые практически больше никто из российских исследователей не ссылается.

Как и в схеме С.В. Соколовского, «Музееведение» образует самостоятельную исследовательскую область (Б11). «Системы родства» в настоящем исследовании выступают самостоятельным модулем (Мо А в Б12), тогда как у С.В. Соколовского эти сюжеты попадают в «Социальную антропологию» [Соколовский 2003, с. 33-34]. Кроме того, в Б12 Мо Б фиксирует существование исследовательской области «Раннеклассовое государство», а в схеме С.В. Соколовского она попала бы в «Теорию первобытности» [Соколовский 2003, с. 26].

«Социальная антропология» представлена в Б13 и объединяет весьма разнородные группы цитирований. Такое зонтичное название способно объединить разнообразные темы, не вписывающиеся в традиционную для советской этнографии проблематику. По всей видимости, той же логикой руководствовался С.В. Соколовский, тоже собирая под этой «шапкой» разнородные статьи, но не совпадающие по тематике с публикациями в Б13. Единственной совокупностью групп цитирований, достигающей статуса исследовательской области, является модуль А «Традиционные представления о пространстве и времени». В блок «Социальная антропология» можно было бы включить целиком Б14 «Англоязычная антропология», но принципиального значения это не имеет, поскольку исследовательскую область он не образует.

Группы цитирований в Б15 «Этническая экология» находятся на грани формирования исследовательской области: в нем на пороге 2 имеются по одному полноценному кластеру и группированию, но отсутствует плотная сеть, а на пороге 4 - только полноценная плотная сеть Ш28 «Этническая экология и физическая антропология» и не достигающие установленных количественных критериев К0320 и Г55. 
Б16 охватывает этноконфессиональную проблематику. Имеющийся здесь модуль А мог бы быть помещен и в Б5 вместе с другой темой, связанной с народами уральской семьи. Модуль Б охватывает проблематику, которая в литературе выступает под названием «шаманство», или «шаманизм». В модуле В объединены группы цитирований, связанные с исламом на территории Российской империи и СССР. Наконец, модуль Г включает таблицы с домонотеистическими религиями и их пережитками, не достигая при этом статуса исследовательской области. В целом блок соответствует рубрике «Этнорелигиоведение» у С.В. Соколовского, также как состоящий из двух модулей (А «Теории этноса и этничности» и Б «Евразийство, Л.Н. Гумилев и их критики») Б17 соответствует его рубрике «Теории этноса и этничности» [Соколовский 2003, с. 24].

В Б18 имеется одна большая исследовательская область - модуль А «Нации, национализм, этнонациональная политика». Все остальные модули не достигают уровня исследовательских областей. Еще более сложная ситуация наблюдается в Б19: здесь выделяются два модуля (А «Этносоциология и этнопсихология» и Б «Этнопсихология»), которые по количественным характеристикам входящих в них таблиц не достигают статуса исследовательских областей. В Б20 отчетливо выделяется только модуль А «Диаспоры». Наконец, в Б21, являющемся собранием таблиц, которые не попали во все предыдущие блоки, выделяется лишь один модуль, который на пороге 2 выступает как «Визуальные исследования» ${ }^{33}$, а на двух более высоких порогах превращается в «Семиотику социальной коммуникации».

Подведем итоги.

1. Проведенное исследование демонстрирует, что анализ социтирований, осуществленный с помощью нескольких количественных методов, позволяет вычленять из массива журнальных ссылок исследовательские области в социальных науках, что ранее для русскоязычных журналов по общественным наукам было только гипотетическим предположением.

2. Набор выделенных в ходе исследования исследовательских областей далек от того набора рубрик, который предложен С.В. Соколовским на основе применения другого метода и другой выборки за иной временной период. Однако можно утверждать, что даже при работе с выборкой С.В. Соколовского анализ социтирований дал результаты, отличные от результатов этого автора.

3. Исследование не позволяет с уверенностью говорить о целом ряде таких исследовательских областей, как общие теории в этнологии, этносоциология, гендерные исследования, этнографические африканистика, европеистика, американистика и некоторых других региональных специализаций, хотя мы можем обнаружить соответствующие подразделения в составе ИЭА РАН и МАЭ РАН. Это не означает отрицания существования данных областей в когнитивной структуре российской науки и не подвергает сомнению выводы С.В. Соколовского, а лишь указывает на недостатки использованного в предложенном в данной статье исследовании инструментария. Возможно, для наращивания объема выборки есть смысл работать с данными за десятилетний период и сравнивать их, скажем, каждые пять лет, чтобы уловить тенденции изменения научных интересов этнологов. Другим моментом может быть уточнение критериев для признания группы

33 Здесь на пороге 2 присутствует полноценное группирование и кластер, в котором цитирований несколько меньше, чем требуется для соответствия величине количества публикаций в таблице. 
цитирований идентифицированной: например, понижение доли публикаций в группе до менее $50 \%$ совпадений с названием группы ${ }^{34}$.

Продолжением работы в данном направлении будет сравнение полученных выводов с результатами анализа когнитивной структуры англоязычной антропологии за тот же временной период.

\section{Литература}

Азадовский М.К. (2013) История русской фольклористики. 2-е изд. Т. 1. М.: Российский государственный университет.

Гинзбург В.В. (1963) Элементы антропологии для медиков. Ленинград: Государственное издательство медицинской литературы.

Маршакова И.В. (1973) Система связей между документами, построенная на основе ссылок (по указателю Science Citation Index) // Научно-техническая информация. Cep. 2: Информационные процессы и системы: ежемесячный научно-технический сборник. № 6. С. 3-8.

Маршакова И.В. (1981) Сети цитирования: информационные модели системы научных публикаций. (По данным отечественной и зарубежной печати 1970-1980 гг.). Сер. 9 «Экономика и системы управления». Вып. 1 (760). М.: ЦНИИ «Электроника».

Маршакова-Шайкевич И.В. (2004) Классификация научных журналов методом коцитирования // Научно-техническая информация. Сер. 1. «Организация и методика информационной работы». № 8. С. 31-35.

Сафонова М.А., Винер Б.Е. (2013) Сетевой анализ социтирований этнологических публикаций в российских периодических изданиях: предварительные результаты // Социология: 4М. № 36. С. 140-176.

Соколовский С.В. (2003) Российская этнография в конце XX в. (библиометрическое исследование) // Этнографическое обозрение. № 1. С. 3-53.

Уитли Р. (1980) Когнитивная и социальная институционализация научных специальностей и областей исследования // Мирский Э.М., Юдин Б.Г. (ред.) Научная деятельность: структура и институты. М.: Прогресс. С. 218-256.

Arabie P., Hubert L.J, Carroll J.D. (2005) Clustering // Encyclopedia of Social Movement. Vol. 1. (ed. Kempf-Leonard K.), Amsterdam: Elsivier, pp. 317-320.

Gmür M. (2003) Co-citation Analysis and the Search for Invisible Colleges: A Methodological Evaluation // Scientometrics, vol. 57, no 1, pp. 27-57.

Kaufman L., Rousseeuw P.J. (1990) Finding Groups in Data: An Introduction to Cluster Analysis, New York: John Wiley and Sons, Inc.

Mullins N.C., Hargens L.L., Hecht P.K., Kick E.L. (1977) The Group Structure of Co-citation Clusters: A Comparative Study // American Sociological Review, vol. 42, no 4, pp. 552-562.

Ortner S.B. (1984) Theory in Anthropology since the Sixties // Comparative Studies in Society and History, vol. 26, no 1, pp. 126-166.

\footnotetext{
34 Возможно, кто-то из читателей ожидает от этой статьи более твердых выводов. В свое оправдание можно привести лишь высказывание одного из учителей автора статьи, профессора Университета Техаса в Остине Норвала Гленна, которое он любил повторять на своих семинарах: «Людям с высокой психологической потребностью в определенности не следует заниматься социальными исследованиями». Увереннее о когнитивной структуре российской этнологии мы сможем говорить лишь после неоднократного ее изучения разными исследователями с помощью разных методов и их модификаций. В качестве примера ответственного, критичного отношения к собственным наукометрическим изысканиям следует процитировать вывод Г. Смолла из его исследования о микроэволюции исследовательских фронтов: «В данный момент мы не имеем достаточных свидетельств, чтобы сказать, представляет ли каждый из этих случаев действительную микроэволюцию. Конечно, расширение нашего исследования на фронты со слияниями и расколами или принятие другого критерия революционного изменения может изменить картину» [Small 2003, p. 398].
} 
Schildt H.A., Mattson J.T. (2006) A Dense Network Sub-grouping Algorithm for Co-citation Analysis and its Implementation in the Software Tool Sitkis // Scientometrics, vol. 67, no 1, pp. 143-163.

Schutt R.K. (1996) Investigating the Social World: The Process and Practice of Research, Thousand Oaks, CA: Pine Forge Press.

Small H. (1973) Co-citation in the Scientific Literature: a New Measure of the Relationship Between Two Documents // Journal of the American Society for Information Science, vol. 24, no 4, pp. 256-269.

Small H. (2003) Paradigms, Citations, and Maps of Science: a Personal History // Journal of the American Society for Information Science and Technology, vol. 54, no 5, pp. 394-399.

Small H., Griffith B.C. (1974) The Structure of Scientific Literatures I: Identifying and Graphing Specialties // Science Studies, vol. 4, no 1, pp. 17-40.

Upham S.P., Small H. (2010) Emerging Research Fronts in Science and Technology: Patterns of New Knowledge Development // Scientometrics, vol. 83, no 1, pp. 15-38.

van Dongen S. (2000) Graph Clustering by Flow Simulation. PhD Thesis, University of Utrecht. May 2000 // http://igitur-archive.library.uu.nl/dissertations/1895620/inhoud.htm

Whitley R. (1974) Cognitive and Social Institutionalization of Scientific Specialties and Research Areas // Social Processes of Scientific Development (ed. Whitley R.), Boston, MA: Routlege \& K. Paul, pp. 69-95.

\title{
Russian Ethnology at the Beginning of the 21th Century: The Cognitive Structure of the Discipline Based on Journal Co-citation Analysis
}

\author{
B. WIENER*
}

\begin{abstract}
*Boris Wiener-PhD in Sociology, Senior Researcher, Sociological Institute, Russian Academy of Sciences. Address: 25/14, 7th Krasnoarmeiskaya St. Petersburg, 190005, Russian Federation. E-mail: wienerras@yandex.ru

Citation: Wiener B. (2017) Russian Ethnology at the Beginning of the 21th Century: The Cognitive Structure of the Discipline Based on Journal Co-citation Analysis. Mir Rossii, vol. 26, no 3, pp. 165-193 (in Russian). DOI: 10.17323/1811-038X-2017-26-3-165-193
\end{abstract}

\begin{abstract}
This paper describes the cognitive structure of Russian ethnology using co-citation analysis. The sample includes references from papers in 159 Russian ethnological and sociological journals and 9 periodical collections of papers published between 2005 and 2009. Three types of methods of quantitative analysis are employed: hierarchical divisive cluster analysis, a dense network sub-grouping algorithm for co-citation analysis, and social network analysis. The triangulation of several methods helps distinguish robust research domains from journal references. The findings differ from those obtained by Sokolovsky in his analysis, which was carried out on the papers
\end{abstract}


published in Etnographicheskoe obozrenie between 1975 and 2000. More specifically, the study reveals the existence of additional research domains that correspond to regions unrecognized in Sokolovsky's research, such as 'East Slavic Ethnology and Folklore,' 'Siberian Ethnology,' 'The Ethnology of Uralic Language Family Peoples,' and 'Central Asian Ethnology' (in addition to Sokolovsky's 'Soviet and Russian Ethnology as a research discipline,' 'Ethnos and Ethnicity,' and others). Also the study does not confirm the existence of such research domains as 'The sociology of ethnic relations,' 'Ethnic Studies of Gender Studies,' 'African Ethnology' and some others, even though the Institute of Ethnology and Anthropology of the Russian Academy of Sciences and the Museum of Anthropology and Ethnology (Kunstkamera) feature corresponding divisions within their structure.

Key words: sociology of social sciences, co-citation analysis, Russian ethnology, scientometrics, bibliometrics, cognitive structure of science

\section{References}

Arabie P., Hubert L.J, Carroll J.D. (2005) Clustering. Encyclopedia of Social Movement. Vol. 1. (ed. Kempf-Leonard K.), Amsterdam: Elsivier, pp. 317-320.

Azadovskij M.K. (2013) Istoriya russkoj folkloristiki [History of Russian Folkloristics]. Second edition. Vol. 1, Moscow: Rossijskij gosudarstvennyij universitet.

Ginzburg V.V. (1963) Elementy antropologii dlya medikov [The Elements of Anthropology for Physicians], Leningrad: Gosudarstvennoe izdatelstvo meditsinskoj literatury.

Gmür M. (2003) Co-citation Analysis and the Search for Invisible Colleges: A Methodological Evaluation. Scientometrics, vol. 57, no 1, pp. 27-57.

Kaufman L., Rousseeuw P.J. (1990) Finding Groups in Data: An Introduction to Cluster Analysis, New York: John Wiley and Sons, Inc.

Marshakova I.V. (1973) Sistema svyazej mezhdu dokumentami, postroennaya na osnove ssylok (po ukazatelyu Science Citation Index) [The System of Document Connections Based on References (data of SCI)]. Nauchno-tehnicheskaya informatsiya. Ser. 2: Informatsionnyie protsessyi i sistemyi: ezhemesyachnyiy nauchno-tehnicheskiy sbornik, no 6, pp. 3-8.

Marshakova I.V. (1981) Seti tsitirovaniya: informatsionnye modeli sistemy nauchnykh publikatsiy (po dannym otechestvennoj i zarubezhnojj pechati 1970-1980 gg.) [Citation Networks: Information Models for the System of Research Publications], Moscow: TsNII "Elektronika".

Marshakova-Shajkevich I.V. (2004) Klassifikatsiya nauchnyikh zhurnalov metodom kotsitirovaniya [Classification of Scientific Journals Using Co-citation Method]. Nauchnotekhnicheskaya informatsiya, no 8, pp. 31-35.

Mullins N.C., Hargens L.L., Hecht P.K., Kick E.L. (1977) The Group Structure of Co-citation Clusters: A Comparative Study. American Sociological Review, vol. 42, no 4, pp. 552-562.

Ortner S.B. (1984) Theory in Anthropology since the Sixties. Comparative Studies in Society and History, vol. 26, no 1, pp. 126-166.

Safonova M.A., Wiener B.E. (2013) Setevoj analiz sotsitirovanij etnologicheskikh publikatsij V rossijskikh periodicheskikh izdaniyakh: predvaritelnye rezultaty. Sotsiologiya: metodologiya, metody i matematicheskoe modelirovanie, no 36, pp. 140-176.

Schildt H.A., Mattson J.T. (2006) A Dense Network Sub-grouping Algorithm for Co-citation Analysis and its Implementation in the Software Tool Sitkis. Scientometrics, vol. 67, no 1, pp. 143-163.

Schutt R.K. (1996) Investigating the Social World: The Process and Practice of Research, Thousand Oaks, CA: Pine Forge Press. 
Small H. (1973) Co-citation in the Scientific Literature: a New Measure of the Relationship Between Two Documents. Journal of the American Society for Information Science, vol. 24, no 4, pp. 256-269.

Small H. (2003) Paradigms, Citations, and Maps of Science: a Personal History. Journal of the American Society for Information Science and Technology, vol. 54, no 5, pp. 394-399.

Small H., Griffith B.C. (1974) The Structure of Scientific Literatures I: Identifying and Graphing Specialties. Science Studies, vol. 4, no 1, pp. 17-40.

Sokolovskij S.V. (2003) Rossijskaya etnografiya v kontse 20 v. (bibliometricheskoe issledovanie) [Russian Ethnology in the End of the 20th Century (Bibliometric Study)]. Etnograficheskoe obozrenie, no 1, pp. 3-53.

Upham S.P., Small H. (2010) Emerging Research Fronts in Science and Technology: Patterns of New Knowledge Development. Scientometrics, vol. 83, no 1, pp. 15-38.

van Dongen S. (2000) Graph Clustering by Flow Simulation. PhD Thesis, University of Utrecht. May 2000. Available at: http://igitur-archive.library.uu.nl/dissertations/1895620/inhoud. htm, accessed 31 May 2017.

Whitley R. (1974) Cognitive and Social Institutionalization of Scientific Specialties and Research Areas. Social Processes of Scientific Development (ed. Whitley R.), Boston, MA: Routlege \& K. Paul, pp. 69-95.

Whitley R. (1980) Kognitivnaya i sotsial'naya institutsionalizatsiya nauchnykh spetsial'nostej i oblastej issledovaniya [Cognitive and Social Institutionalization of Scientific Specialties and Research Areas]. Nauchnaya deyatel'nost': struktura i instituty [Scientific Activities: Structure and Institutions] (eds. Mirskij E.M., Yudin B.G.), Moscow: Progress, pp. 218-256. 